\title{
Two possible candidate enzymes from Ulva lactuca-associated epiphytic bacteria obtained through PCR and functional evaluation
}

\author{
Ruiz-Toquica Jordan Steven ${ }^{1}$; Comba-González Natalia Beatriz ${ }^{1}$ Montoya-Castaño Dolly ${ }^{1, *}$
}

Edited by

Juan Carlos Salcedo-Reyes

(salcedo.juan@javeriana.edu.co)

1. Grupo de Bioprocesos y

Bioprospección, Instituto de

Biotecnología, Universidad

Nacional de Colombia,

Carrera 45 No. 26 - 85, Bogotá,

Colombia, ZIP Code: 111321.

*dmontoyac@unal.edu.co

Received: 02-04-2019

Accepted: 18-05-2020

Published on line: 17-07-2020

Citation: Ruiz-Toquica JS,

Comba-González NB,

Montoya-Castaño D. Two possible

candidate enzymes from Ulva

lactuca-associated epiphytic bacteria

obtained through PCR and functional

evaluation, Universitas Scientiarum,

25 (2): $247-275,2020$.

doi: 10.11144/Javeriana.SC25-2.tpce

\section{Funding:}

Instituto de Biotecnología de la

Universidad Nacional de Colombia,

the Direction of Research and

Extension, the Faculty of Sciences

of the Universidad Nacional

de Colombia, and the "Jóvenes

Investigadores" Scholarship Program

of Colciencias.

Electronic supplementary

material: N.A.

OPEN ACCESS

\begin{abstract}
Epiphytic bacteria from marine macroalgae synthesize enzymes of industrial and biotechnological interest. In this study, we obtained two DNA candidate fragments for lipid-degrading enzymes from the total DNA of Ulva lactuca-associated epiphytic bacteria. First, we evaluated a method for total bacterial DNA isolation from the surface of $U$. lactuca thalli. Then, we designed sets of primers and used them directly for PCR amplification. The resulting PCR products were sequence-analyzed and used for expression and functional evaluation with the Escherichia coli pBAD-TOPO system. We obtained high molecular weight and good quality total bacterial DNA that served as a template to identify a fragment corresponding to an Acetyl-CoA C-Acetyltransferase (or Thiolase), and a candidate fragment for a versatile "true" lipase. We expressed the possible "true" lipase gene fragment heterologously in Escherichia coli and obtained proof of hydrolytic activity on Tributyrin, Tween-20, and Olive-oil media. This study resulted in new knowledge on $U$. lactuca-associated epiphytic bacteria as possible brand-new sources of enzymes such as thiolases and "true" lipases. However, future studies are required to describe the characteristics and important applications of these candidate enzymes.
\end{abstract}

Keywords: Epiphytic bacteria; lipases; PCR; thiolases; Ulva lactuca.

\section{Introduction}

The surfaces of marine macroalgae represent promising candidate sources of novel biocatalysts [1]. These surfaces are exposed to different conditions of temperature and salinity and are also important nutrient-rich environments 
that enable bacterial colonization and constitute sustainable microhabitats [2]. Bacteria living on macroalgal surfaces (also called epiphytes) promote host development and health, providing $\mathrm{CO}_{2}$ and minerals. Furthermore, these epiphytes produce specific regulatory factors and antagonistic compounds that promote and enhance algal growth, defense, resilience, and facilitate stress response [3, 4]. On the other hand, the epiphytic bacteria benefit from the organic matter produced by the macroalgae and synthesize a vast variety of enzymes to assimilate these compounds [5-7]. For instance, macroalgae from the species of Ulva lactuca have an important content of lipids (8 - 3\% dry weight), especially palmitic and oleic acids $[8,9]$; therefore, associated epiphytic bacteria may need to synthesize enzymes such as esterases, lipases, and thiolases [10], among wide variety of other enzymes [11].

Lipases are enzymes that act on triglycerides ester bonds to liberate fatty acids and glycerol, thus participating in lipid degradation and biosynthesis pathways [12]. Likewise, lipases have an enormous catalytic versatility including lipid hydrolysis, trans- and inter-esterification, fat and oil acidolysis, aminolysis, and alcoholysis [13, 14]. Due to these features, lipases have a variety of applications in the food, pharmaceutical, and cosmetic industries, as well as in the production of agrochemicals, biofuels, and detergents, among others $[15,16]$. Lipases are divided into two main groups: esterases (EC.3.1.1.1) that prefer water-soluble short-chain fatty acids, and "true" lipases or triacylglycerol hydrolases (EC.3.1.1.3) that prefer low water-soluble long-chain fatty acids $[17,18]$. All lipases share a high conserved active site (Ser-Asp-His) and a consensus region motif (Gly-Xaa-Ser-Xaa-Gly) [19].

Thiolases (EC.2.3.1.16), also called Acetyl-CoA C-Acetyltransferases, are transferases that catalyze the reversible cleavage of fatty acids into acyl-CoA and acetyl-CoA throughout the transference and condensation of acyl groups $[20,21]$. Further, thiolases are involved in lipid transport and assimilation, $\beta$-oxidation, as well as in fatty acid, steroid, and polyketide biosynthesis [22]. These enzymes also have several applications in the production of organic solvents and biofuels, synthesis and degradation of antibiotics, and bioremediation processes [23-25].

Metagenomics studies have revealed the genetic, metabolic, and functional potential of non-cultivable microorganisms [26, 27]. Besides, access to the total DNA of an environmental sample, PCR-based analysis, and functional evaluation have allowed the discovery of lipolytic genes and enzymes from marine environments [28-30]. For instance, LipG, EstA, EML1, and EstHE1 lipases, displaying high salt tolerance, thermostability, activity within a broad $\mathrm{pH}$ range, and stability in a high concentration of divalent ions and organic 
solvents, have been recovered from the bacterial metagenomes of intertidal flats, coastal environments, deep-sea sediments, and organism-associated bacteria [31-34]. LipA, an alkaline "true" lipase, was described from the metagenome of a marine sponge [35]. Likewise, GmEst_7 and Lip5 quorum sensing lipases were discovered in brown algae epiphytic bacteria $[36,37]$. Further, other studies have reported lipases from the metagenome of the green macroalgae Ulva australis, such as the abg3 gene that encodes a $\beta$-lactamase-like lipase that displays lipolytic activity and confers antibacterial properties, as shown in a heterologous expression study [38].

Nonetheless, despite "true" lipases and thiolases being important enzymes in several biotechnology and industrial applications, there is limited information about these enzymes in green macroalgae-associated bacteria; therefore, the question arises whether epiphytic bacteria from $U$. lactuca produce "true" lipases and thiolases. In consequence, here we present a suitable method for total bacterial DNA isolation from $U$. lactuca surfaces and a PCR-based identification of these enzymes and closely related enzymes. We found a candidate DNA sequence for a thiolase, and a DNA fragment that displayed "true" lipase activity when was functionally expressed. Our results showed that $U$. lactuca-associated epiphytic bacteria are potential sources of biocatalysts of marine origin.

\section{Material and Methods}

\section{Strains, plasmids and media}

Lipase-producing strains of Burkholderia cepacia and Psendomonas aeruginosa were used as positive controls, and Escherichia coli DH5 $\alpha$ was used as the negative control. These strains are part of the "Banco de Cepas y Genes del Instituto de Biotecnología de la Universidad Nacional de Colombia”. E. coli TOP10 and plasmid pBAD-TOPO (Invitrogen) were used for cloning/expression assays. Luria Bertani agar $(10 \mathrm{~g} / \mathrm{L}$ tryptone, $10 \mathrm{~g} / \mathrm{L} \mathrm{NaCl}, 5 \mathrm{~g} / \mathrm{L}$ yeast extract, $15 \mathrm{~g} / \mathrm{L}$ bacteriological agar) supplemented with tributyrin $1 \% \mathrm{v} / \mathrm{v}$ and $0.2 \mathrm{ml} / \mathrm{L}$ triton X-100 (emulsifier) was used for lipase screening. To confirm lipolytic activity, Tween 20 (10 g/L peptone, $5 \mathrm{~g} / \mathrm{L} \mathrm{NaCl}, 15 \mathrm{~g} / \mathrm{L}$ bacteriological agar, $1.1 \mathrm{~g} / \mathrm{L} \mathrm{CaCl} 2$ and $10 \mathrm{ml} / \mathrm{L}$ Tween 20) and Rhodamine-Olive Oil-Agar $(8 \mathrm{~g} / \mathrm{L}$ nutrient broth, $4 \mathrm{~g} / \mathrm{L} \mathrm{NaCl}, 15 \mathrm{~g} / \mathrm{L}$ bacteriological agar, $10 \mathrm{ml} / \mathrm{L}$ Olive Oil and $10 \mathrm{ml} / \mathrm{L}$ Rhodamine B) were also used. Some culture media contained $0.1 \mathrm{mg} / \mathrm{L}$ ampicillin antibiotic. 


\section{Sample collection and total DNA isolation}

Thalli of green macroalgae $U$. lactuca were collected at 'La Punta de la Loma'

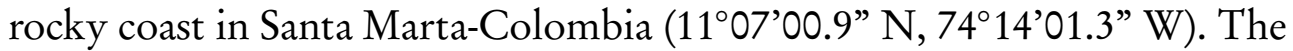
samples were washed several times with sterile seawater and then transferred into sterile refrigerated plastic bags and stored at $-80^{\circ} \mathrm{C}$ until processing. Afterward, total bacterial DNA from the macroalgal surface was isolated using the ZR Soil Microbe DNA Kit (Zymo Research). Between $0.6 \mathrm{~g}$ and $1.0 \mathrm{~g}$ of the thallus base section was placed into tubes containing silica-beads and lysis buffer [39]. On a Bead-Beater (Disruptor Genie ${ }^{\mathrm{TM}}$, United States) tube holder, physical disruption of bacterial cells was performed at maximum speed for 1.5-min pulses, twice, with a 5 -min rest on ice between pulses [40, 41]. Then, tubes were centrifuged at maximum speed and the clear supernatant was transferred and further processed according to the manufacturer's protocol. In the end, total DNA was eluted in $20 \mu \mathrm{l}$ buffer and then stored at $-20{ }^{\circ} \mathrm{C}$. In addition, total DNA was analyzed by electrophoresis on agarose gel, and DNA yield ( $\mathrm{ng} / \mathrm{\mu l}$ ) and quality (Abs at 260/280 nm) were quantified with a Nanodrop 2000C.

\section{Primer design}

The Abg3 gene (from $U$. australis) was used to design primers for homologous sequences. The region between 21704 - 22681 bp of the UaAb1 clone fosmid (HQ162719) corresponding to the open reading frame (ORF) [42], was targeted for primer design through the Primer-BLAST (NCBI) tool. In order to include the whole sequence, we picked the most suitable set of primers (labeled UaLip) to be synthesized. In parallel, a set of degenerate primers was designed using a consensus region of nine representative and highly related "true" lipase sequences from different bacteria [43]. First, the alignments were carried using CLUSTAL OMEGA and the consensus region was determined through the Block-Maker tool. Then, the conserved blocks were directly fed to the CODEHOP (Consensus-Degenerate Hybrid Oligonucleotide Primers) program [44, 45]. Default values were used except for degeneracy (256), degeneracy strictness (2.5), and codon usage (bacteria and plastids -gbbct-). The primers (labeled LipFam1) were picked in order to include the whole consensus sequence, and were tested for specificity and universality using BLASTx. Lastly, these sets of primers were characterized via Multiple Primer Analyzer (Thermo Fisher Scientific) and Oligo-analyzer (Integrated DNA Technologies) tools and then contrasted with reported optimal values for PCR [46-48]. Oligo sequences are listed in Table 1. 
Table 1. Set of primers used in this study. ${ }^{\text {a }}$ : A, C, G or T; Y: C or T; D: A, G or $\mathrm{T} .{ }^{\mathrm{b}}$ Degenerate sites are labelled in bold and underlined.

Primers Sequence $\left(5^{\prime} \rightarrow 3^{\prime}\right)^{a, b}$

LipFam1F GGTACCCCATCGTCCTG

LipFam1R CCAGTGGTAGTCGGTCCTGATNACNTDNCC

UaLipF AGCGATAATGAAACGGGCCA

UaLipR TCCGTTGATGATGCCGCTTA

Amplification of the target genes by PCR

Hot-Start PCR mixes contained: $1 \mathrm{X}$ Taq Buffer, $0.5 \mathrm{mM}$ dNTPs, $0.5 \mu \mathrm{M}$ of each primer, $2.0 \mathrm{mM} \mathrm{MgCl}$, $2 \%$ DMSO (Dimethyl-Sulfoxide), $0.5 \mathrm{mg} / \mu 1$ BSA (Bovine Serum Albumin) and $1 \mathrm{U} / \mu \mathrm{l}$ Taq Polymerase. Total bacterial DNA from U. lactuca surface was used as template (50-100 ng) for UaLip and LipFam1 primers testing. Amplification using UaLip primers was performed following these conditions: $95^{\circ} \mathrm{C}$ for $5 \mathrm{~min}, 30$ cycles of $94^{\circ} \mathrm{C}$ for $30 \mathrm{~s}, 61^{\circ} \mathrm{C}$ (optimal) for $30 \mathrm{~s}$ and $72{ }^{\circ} \mathrm{C}$ for $1 \mathrm{~min}$, plus a final extension step at $72{ }^{\circ} \mathrm{C}$ for $10 \mathrm{~min}$. Amplification using LipFam1 primers was carried under the same conditions with a slight modification on annealing temperature: $53^{\circ} \mathrm{C}$ (optimal) for $1 \mathrm{~min}$. Then, PCR products were visualized on a $2 \%$ agarose gel and purified using gel extraction with Gene JET Gel Extraction Kit (Thermo Fisher Scientific). Additionally, genomic DNA from "true" lipase producing strains was used as positive control to test LipFam1 primers.

Expression of a possible "true" lipase gene fragment

Some purified DNA fragments obtained from total DNA of $U$. lactuca surface using LipFam1 primers, were cloned and expressed through pBAD TOPO system, following the manufacturer's instructions. The cloning reaction was performed at a vector: insert molar ratio of 3:1 and then, chemically 
competent cells were transformed by heat-shock and spread on LB agar plates containing tributyrin $1 \% \mathrm{v} / \mathrm{v}$ and ampicillin. Cells transformed with empty vectors were used as the negative control. Positive clones were randomly selected and confirmed on Tween 20 and Olive-oil agar plates. Activity on tributyrin-LB agar was observed by the formation of a clear zone around the colony [49-51]. Enzymatic activity on Tween 20 was identified through the formation of a white precipitate below the colonies [52-54]; and on Olive-oil agar by the irradiation of fluorescence under UV light [55].

\section{Sequence Analysis}

All the cleaned and purified PCR products were SANGER sequenced at the 'Instituto de Genética de la Universidad Nacional de Colombia'. The sequences obtained were analyzed and edited through the BioEdit program, and the resulting high-quality FASTA files were contrasted against RefSeq Nucleotide database using BLASTn. Functional protein domains were searched using BLASTx against non-redundant UniProtKB/Swiss-Prot Protein database.

\section{Nucleotide Sequence Accession Numbers}

The accession numbers of the nucleotide sequences used in degenerate primers design were: AAA50466, CAA32193, AAB01071, AEK97793, AAC05510, CAA49812, GAC32742, WP_016349285, and AGE44121.

\section{Results}

\section{Total DNA isolation}

About $0.8 \mathrm{~g}-0.9 \mathrm{~g}$ of $U$. lactuca thalli were optimal to obtain high molecular weight bacterial DNA $(\geq 10 \mathrm{~Kb})$ (Fig. 1). The yield of total DNA was approximately $0.01 \mu \mathrm{g} / \mathrm{g}-0.1 \mu \mathrm{g} / \mathrm{g}$ per algal sample (from $11.17 \pm 0.27$ to $75.62 \pm 0.23 \mathrm{ng} / \mu \mathrm{l})$. DNA purity was homogeneous after each extraction (from $1.6 \pm 0.09$ to $1.8 \pm 0.05260 / 280 \mathrm{~nm}$ ). Despite observed degradation, total DNA was appropriate for PCR amplification.

\section{Identification of a Thiolase DNA fragment}

After PCR reactions with epiphytic bacterial total DNA, a $\sim 1.0 \mathrm{~kb}$ fragment (8-12 ng/ $\mu \mathrm{l}$ ) (Fig. 2A) was effectively obtained using the UaLip primers. After sequencing and editing, our BLASTn search revealed that a $519 \mathrm{pb}$ high quality sequence had the most similarity to an Acetyl-CoA C-Acetyltransferase (or Thiolase) from Erythrobacter litoralis (75\% of identity, $\mathrm{E}$-value $=2 \mathrm{e}-35)$. After the analysis, an open reading frame $(90 . .446 \mathrm{pb})$ 


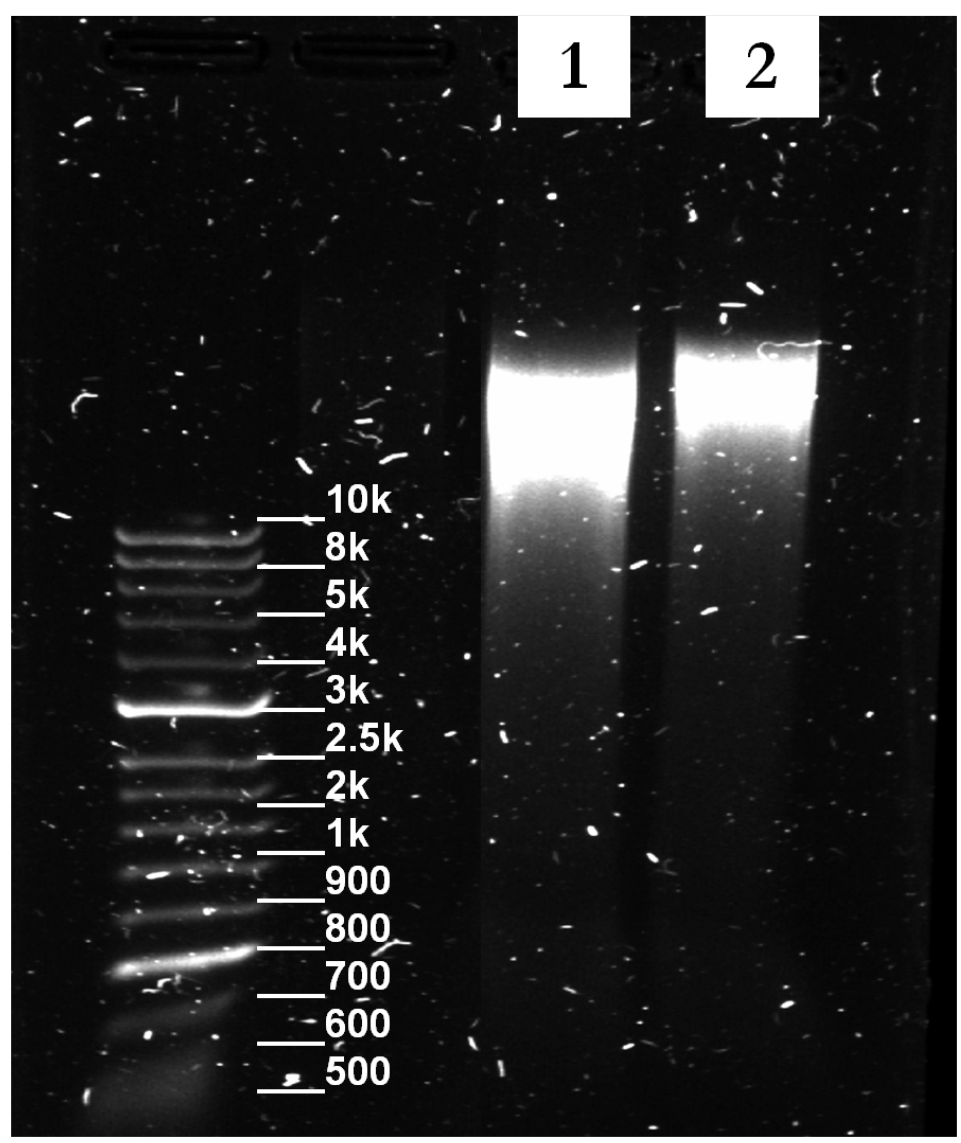

Figure 1. Total bacterial DNA from samples of the thallus of Ulva lactuca. The agarose gel shown was run with $1 \mathrm{~Kb}$ Opti-DNA Marker $\left(\mathrm{abm}^{\circledR}\right)$.

was detected and corresponded to a 118 aa product. Thiolase (cd00751), Acetyl-CoA acetyltransferase (PRK06025) and PaaJ (COG0183) domains were identified. Additionally, the obtained nucleotide sequence was uploaded to the Genbank with accession number MK418067.

\section{Identification of a "True" lipase DNA fragment}

On the other hand, PCR amplification with the degenerate primers LipFam1 on the total bacterial DNA from $U$. lactuca surface and on the B. cepacia and P. aeruginosa genomic DNA, resulted in $\sim 2.0 \mathrm{~kb}$ fragments $(14 \mathrm{ng} / \mu \mathrm{l}-$ $20 \mathrm{ng} / \mu \mathrm{l}$ ) (Fig. 2B). However, no data was recovered after sequencing due to the low quality and short length of the reads. Despite this, some PCR products were effectively cloned and expressed in E. coli TOP10 (efficiency $1-5 \times 10^{6} \mathrm{UFC} / \mu \mathrm{g}$ DNA). The clones tested on tributyrin-LB showed a clear zone around the colonies (Fig. 3A and Fig. 3C) while on tween-20 agar, a white precipitate was observed below the colonies and widespread all over the plate (Fig. 3B). Likewise, clones tested on olive-oil agar (Fig. 4A) showed a strong visible fluorescence all over the colony after exposure to UV-light 


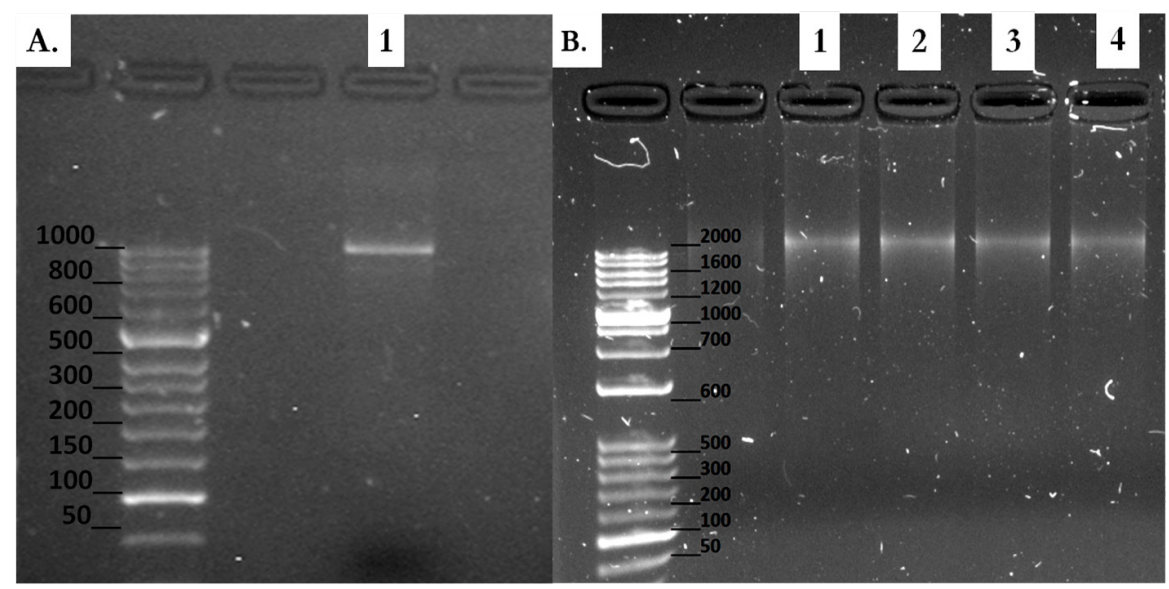

Figure 2. Purified DNA fragments obtained from PCR reactions. A) $\mathrm{A} \sim 1.0 \mathrm{~kb}$ fragment (1) obtained using the UaLip primers on total bacterial DNA from the surface of $U$. lactuca. B) A $\sim 2.0 \mathrm{~kb}$ fragment obtained using the LipFam1 primers on the total bacterial DNA (1 and 2), and on the genomic DNA of the positive controls B. cepacia (3) and P. aeruginosa (4). Gel A was run with GeneRuler ${ }^{\mathrm{TM}} 50 \mathrm{pb}$ DNA Ladder (Thermo Scientific) while gel B with Hyper-Ladder $^{\text {TM }} 50$ pb (Bioline).

(Fig. 4B and C). Similarly, positive controls used to compare the "true" lipase activity showed fluorescence all around the colony (Fig. 4D and E) while negative control ("true" lipase non-producing strain) showed no fluorescence (Fig. 4F) after exposure.

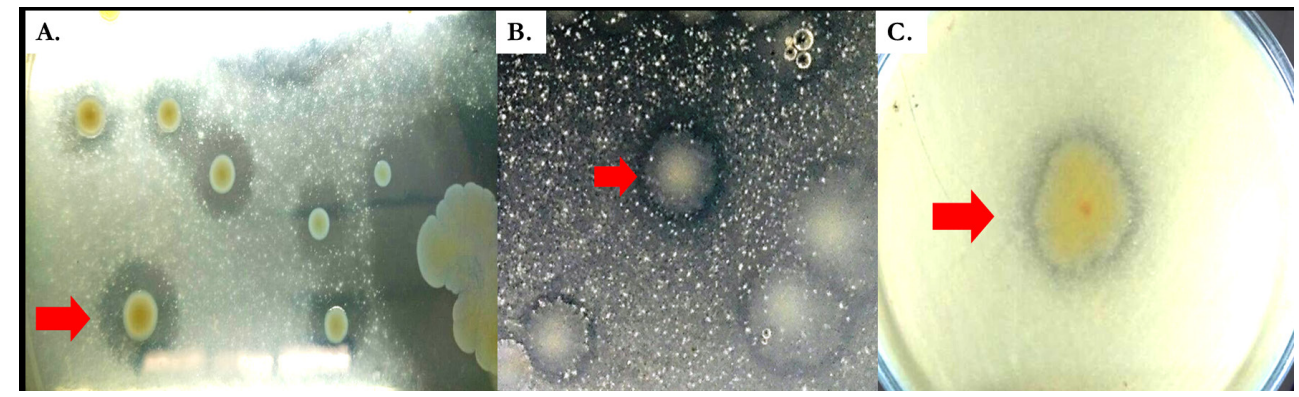

Figure 3. Lipase activities (red arrows) of the expressed LipFam1 PCR products obtained from the total DNA of sample from the surface of $U$. lactuca. The LipFam 1 clone-libraries were tested on: A) Tributyrin agar, showing wide clear zones around the colonies as a result of the loss of emulsion due to the release of the soluble fatty acids and glycerol from the tributyrin; and B) on Tween 20 agar displaying a white precipitate below the colonies as a result of the salt-formation between the free fatty acids and the $\mathrm{Ca}^{2+}$ in the medium after the hydrolysis of the tween 20. C) Lipase activity of a single colony (clone 9) on Tributyrin agar. 


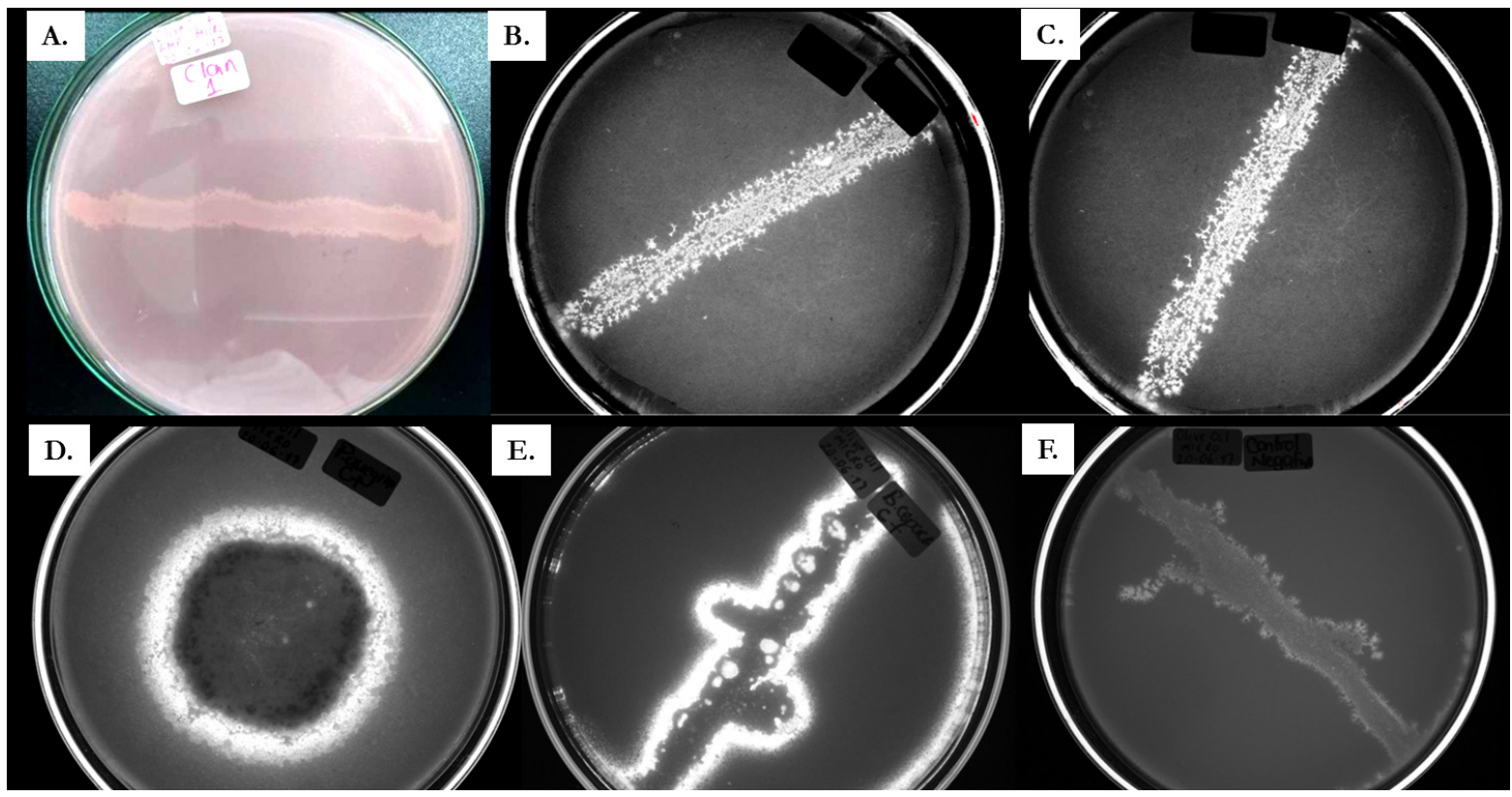

Figure 4. True-lipase activity evaluations on olive-oil agar. A) Clone 1 before exposure to UV-light, B) and C) Clones 1 and 9, respectively, after exposure to UV-light. D) $P$. aernginosa positive control (inoculated by puncture). E) $B$. cepacia positive control (inoculated by spreading). F) E. coli $\mathrm{DH} 5 \alpha$ negative control. The activity was observed by the irradiation of fluorescence as a result of the interaction between the free fatty acids from the olive oil and the Rhodamine B dye in the medium. The negative control did not show any fluorescence after the exposure.

\section{Discussion}

\section{Total DNA isolation}

The surfaces of macroalgae harbor communities of epiphytic bacteria [2] with broad regulatory roles on macroalgal growth, development, nutrient supply, protection, adaptation, and stress resilience [56]. Likewise, these bacteria may benefit from organic compounds secreted by the algal host. These compounds can be degraded by enzymes that are synthesized by epiphytic bacteria [5]. For this reason, algal surfaces are an important source of a variety of enzymes [36, 57]. Different methodologies have been used for screening enzymes of bacterial origin. This study followed the Burke's standardized method $[39,42]$ with some suitable modifications for obtaining DNA isolated of epiphytic bacteria. Total DNA was used for PCR-based analysis and subsequent functional evaluation [58]. To isolate bacterial DNA, we selected the thallus base section of $U$. lactuca due to the high density of bacteria 
present there (around to $10^{7}$ cells $/ \mathrm{cm}^{2}$ ), which decreases closer to the distal tips (around to $10^{2}$ cells $/ \mathrm{cm}^{2}$ ) [2, 59]. Moreover, we attempted physical cell disruption to release the bacteria from the thallus surface as suggested by Longford et al. [60]. Various studies have shown that this technique allows the isolation of DNA from bacteria with complex cell walls (thicker peptidoglycan layers) such as Actinobacteria and Firmicutes, which occur at low densities [61] at the surface of Ulva species [62, 63]. Additionally, the methodology used in this study allows DNA clean-up [64, 65] throughout the filtration of possible inhibitors such as phenolic and humic compounds that bind to amine groups from the DNA and that negatively affect the PCR reactions [66]. Therefore, the total bacterial DNA isolated in this study served as a template for PCR-based analysis; and additives such as Bovine Serum Albumin (BSA) and Dimethyl-sulfoxide (DMSO) were necessary to enhance PCR reactions [67-69].

\section{Identification of a Thiolase}

Although no data was recovered for the abg3 gene reported by Burke [42], we identified a $1.0 \mathrm{~kb}$ fragment corresponding to a "thiolase gene". Thiolases are a group of enzymes that have important uses on cellular engineering for industrial processes [70]. These enzymes appear to be functionally closely related to lipases and esterases since they are involved in the same lipid-degrading pathways and show genetic proximity to thioesterases [71]. In consequence, we gather that the presence of this thiolase on the total bacterial DNA from the $U$. lactuca surfaces could strongly entail lipolytic functions in the epiphytic bacterial communities. Thiolases could be involved in biotic degradation of some lipids on the algal host surface, considering that these enzymes participate in the cleavage of mid and long-length fatty acids in $\beta$-oxidation catabolism $[25,72]$. Thiolases also catalyze reactions involved in lipid transport [73], biosynthetic metabolism [74], host stress-response [75], and bacterial virulence [76], which necessarily include the use of lipid backbones as different authors have pointed.

It is well known that thiolases are widely distributed among bacteria and eukaryotes and it has been also observed that they possess a promiscuous functionality by catalyzing different reactions [77]. Therefore, thiolases have different roles in cell engineering especially for the polyhydroxyalkanoates (PHAs) [78-80], organic acids and solvents [81, 82], and biofuel overproduction, as well as for wax ester fermentation [83] and bioremediation [84]. In consequence, further studies on thiolases produced by the $U$. lactuca epiphytic communities are required to understand their features and thereby explore their potential applications. 


\section{Identification of a "True" Lipase}

In this study we proposed the LipFam1 primers for the PCR-based identification of "true" lipases; however, no data of its sequence was recovered. A problem in genomics is to functionally classify DNA sequences derived from environmental sampling. Sometimes the query sequence does not have a close relative in the database; this could be the case of the fragment obtained with LipFam1 primers [85].

On the other hand, the bacteria transformed with the PCR products involving the LipFam1 primers showed hydrolytic activity on fatty acids of different chain lengths such as tributyrin (C: 4), tween 20 (C: 12), and olive oil (C: 18). In tributyrin media, the clear halos around the colonies were the result of the loss of emulsion that indicates the release of soluble glycerol and butyric acid after hydrolysis $[12,86]$. The white precipitate was the evidence of the salt formed between the anionic lauric acid from the tween 20 and the $\mathrm{Ca}^{2+}$ ions in the medium after the hydrolase activity $[52,87]$. Furthermore, the fluorescent halos were visible upon UV irradiation due to the interaction between the Rhodamine B dye and the free long-chain fatty acids (such as oleic, linoleic and palmitic) after the hydrolysis of olive oil [88-90]. In consequence, here we infer that this fragment could correspond to a versatile true lipase since it appears to hydrolyze different length-chain fatty acids, in contrast to common true lipases which only are capable of hydrolyzing ester bonds from long-chain fatty acids (> C: 12) in triacylglycerides [17]. Various lipases show a broad substrate specificity and regiospecificity [18] because of a flexible active site that appears to change its conformation with the presence and binding of different substrates [91, 92].

Our work is potentially the first report of a versatile "true" lipase identified on the total DNA of the epiphytic bacteria from $U$. lactuca. Marine "true" lipases have been only identified on the free-living bacteria such as Oceanobacillus sp. [93] and Pseudomonas sp. [94], the metagenomes of the marine sponges Ircinia sp. (LipA) [35] and Haliclona simulans (Lpc53E1) [95], and recently, in the epiphytic bacterium Shewanella algae from the brown macroalgae Ascophyllum nodosum [96]. Although, knowledge of lipases from green macroalgae epiphytic bacteria is limited [57, 97], the efforts to describe and characterize marine lipases from this source have actually shown that cultivable epiphytic bacteria from $U$. lactuca are capable of producing lipases and other hydrolytic enzymes [1].

Future studies on this topic could reveal the features and properties of these "true" lipases from green macroalgae-associated bacteria. Lipases from marine sources have shown attractive characteristics such as thermostability 
[98], high-salt tolerance [99], cold-adaptation [100], extreme $\mathrm{pH}$ tolerance [101], organic solvents tolerance [102], and enantioselectivity [103]. These important properties are largely required in industrial and biotechnological applications such as plastic degradation [104] and biodiesel synthesis [105], as well as anti-biofilm and biofouling additives [106].

\section{Conclusions}

According to the importance of the marine biocatalysts for industrial and biotechnological purposes, here we were able to describe a suitable method to obtain two possible candidate enzymes. These candidates appear to be synthesized by the Ulva lactuca-associated epiphytic bacteria and could play important roles in lipid metabolism and lipid degradation.

One candidate was sequence-identified as a thiolase and the other was functionally-described as a versatile "true" lipase. The presence of these candidates can be related to the lipolytic functions in the U. lactuca-associated bacterial communities, and therefore, could represent a potential source of these enzymes and their related.

Notwithstanding this functional evidence, only nucleotide and peptide sequence analyses of these fragments will confirm our assumptions, and further structural and functional characterizations will reveal the features and properties of these candidates. Finally, these approaches will allow the search of potential candidate enzymes from un-exploited sources, such as green algae-associated epiphytic bacteria.

\section{Acknowledgements}

The authors thank the staff of the Instituto de Biotecnología de la Universidad Nacional de Colombia, the Direction of Research and Extension, the Faculty of Sciences of the Universidad Nacional de Colombia, and the "Jóvenes Investigadores" Scholarship Program of Colciencias for supporting and funding this work. Also, the authors thank María Luna Ramírez and Albert Nicolás Niño for helping in some experimental procedures.

\section{Conflict of interest}

The authors certify that they have no affiliations or involvement in any organization or entity with any financial interest. Also, the authors declare that they have no conflict of interest. 


\section{References}

[1] González NC, Hoyos ML, Kleine LL, Castaño DM. Production of enzymes and siderophores by epiphytic bacteria isolated from the marine macroalga Ulva lactuca, Aquatic Biology 27: 107-118, 2018 .

doi: $10.3354 / \mathrm{ab} 00700$

[2] Egan S, Harder T, Burke C, Steinberg P, Kjelleberg S, Thomas T. The seaweed holobiont: understanding seaweed-bacteria interactions. FEMS Microbiology Reviews, 37: 462-476, 2013.

doi: 10.1111/1574-6976.12011

[3] Goecke F, Labes A, Wiese J, Imhoff JF. Chemical interactions between marine macroalgae and bacteria. Marine Ecology Progress Series, 409: 267-300, 2010.

doi: 10.3354/meps08607

[4] Wahl M, Goecke F, Labes A, Dobretsov S, Weinberger F. The second skin: ecological role of epibiotic biofilms on marine organisms. Frontiers in microbiology, 3: 292, 2012.

doi: 10.3389/fmicb.2012.00292

[5] Martin M, Portetelle D, Michel G, Vandenbol M. Microorganisms living on macroalgae: diversity, interactions, and biotechnological applications. Applied Microbiology and Biotechnology, 98: 2917-2935, 2014.

doi: 10.1007/s00253-014-5557-2

[6] Singh RP, Reddy CRK. Seaweed-microbial interactions: key functions of seaweed-associated bacteria. FEMS Microbiology Ecology, 88: 213-230, 2014.

doi: 10.1111/1574-6941.12297

[7] Martin M, Barbeyron T, Martin R, Portetelle D, Michel G, Vandenbol M. The Cultivable Surface Microbiota of the Brown Alga Ascopbyllum nodosum is Enriched in MacroalgalPolysaccharide-Degrading Bacteria. Frontiers in microbiology, 6: $1487,2015$.

doi: 10.3389/fmicb.2015.01487 
[8] Kostetsky E, Chopenko N, Barkina M, Velansky P, Sanina N. Fatty Acid Composition and Thermotropic Behavior of Glycolipids and Other Membrane Lipids of Ulva lactuca (Chlorophyta) Inhabiting Different Climatic Zones. Marine drugs, 16 (23): 494, 2018.

doi: $10.3390 / \operatorname{md} 16120494$

[9] Yaich H, Garna H, Besbes S, Paquot M, Blecker C, Attia H. Chemical composition and functional properties of Ulva lactuca seaweed collected in Tunisia. Food chemistry, 128 (4): 895-901, 2011.

doi: 10.1016/j.foodchem.2011.03.114

[10] Krohn-Molt I, Wemheuer B, Alawi M, Poehlein A, Güllert S, Schmeisser C, Streit WR. Metagenome survey of a multispecies and algae-associated biofilm reveals key elements of bacterialalgae interactions in photobioreactors. Applied and environmental microbiology, 79 (20): 6196-6206, 2013.

doi: 10.1128/AEM.01641-13

[11] Naik MM, Naik D, Charya L, Mujawar SY, Vaingankar DC. Application of Marine Bacteria Associated with Seaweed, Ulva lactuca, for Degradation of Algal Waste, Proceedings of the National Academy of Sciences. India Section B: Biological Sciences, 89 (4): 1153-1160, 2018.

doi: 10.1007/s40011-018-1034-5

[12] Jaeger KE, Kovacic F. Determination of lipolytic enzyme activities. Pseudomonas Methods and Protocols, 111-134, 2014.

doi: 10.1007/978-1-4939-0473-0_12

[13] Hasan F, Shah AA, Hameed A. Industrial applications of microbial lipases. Enzyme and Microbial Technology, 39 (2): 235251, 2006.

doi: 10.1016/j.enzmictec.2005.10.016

[14] Khan FI, Lan D, Durrani R, Huan W, Zhao Z, Wang Y. The lid domain in lipases: Structural and functional determinant of enzymatic properties. Frontiers in bioengineering and biotechnology, 5: $16,2017$.

doi: 10.3389/fbioe.2017.00016

[15] Jaeger KE, Eggert T. Lipases for biotechnology. Current opinion in Biotechnology, 13 (4): 390-397, 2002.

doi: 10.1016/s0958-1669(02)00341-5 
[16] Javed S, Azeem F, Hussain S, Rasul I, Siddique MH, Riaz M, Nadeem H. Bacterial lipases: a review on purification and characterization. Progress in biophysics and molecular biology, 132: 23-34, 2018.

doi: 10.1016/j.pbiomolbio.2017.07.014

[17] Kovacic F, Babic N, Krauss U, Jaeger K. Classification of Lipolytic Enzymes from Bacteria. Aerobic Utilization of Hydrocarbons, Oils, and Lipids, 24: 255-289, 2019.

doi: 10.1007/978-3-319-50418-6_39

[18] Messaoudi A, Belguith H, Gram I, Hamida JB. Classification of EC 3.1. 1.3 bacterial true lipases using phylogenetic analysis. African journal of biotechnology, 9 (48): 8243-8247, 2010.

doi: $10.5897 /$ AJB10.721

[19] Arpigny JL, Jaeger KE. Bacterial lipolytic enzymes: classification and properties. Biochemical Journal, 343 (1): 177-183, 1999.

doi: 10.1042/bj3430177

[20] Schaefer CM, Lu R, Nesbitt NM, Schiebel J, Sampson NS, Kisker C. FadA5 a thiolase from Mycobacterium tuberculosis: a steroid-binding pocket reveals the potential for drug development against tuberculosis. Structure, 23 (1): 21-33, 2015.

doi: $10.1016 /$ j.str.2014.10.010

[21] Tao T, Liu X, Chang J, Xu F, Yin Y. Cloning and characterisation of the gene encoding acetyl-coa c-acetyltransferase in Matricaria chamomilla. Journal of Pharmaceutical, Chemical and Biological, 4 (3): 386-393, 2016.

https://www.jpcbs.info/2016_4_3_08_Tingting.pdf

[22] Fujita Y, Matsuoka H, Hirooka K. Regulation of fatty acid metabolism in bacteria. Molecular microbiology, 66 (4): 829-839, 2007.

doi: 10.1111 / j.1365-2958.2007.05947.x

[23] Suo Y, Ren M, Yang X, Liao Z, Fu H, Wang J. Metabolic engineering of Clostridium tyrobutyricum for enhanced butyric acid production with high butyrate/acetate ratio. Applied microbiology and biotechnology, 102 (10): 4511-4522, 2018.

doi: 10.1007/s00253-018-8954-0 
[24] Lütke-Eversloh T. Application of new metabolic engineering tools for Clostridium acetobutylicum. Applied microbiology and biotechnology, 98 (13): 5823-5837, 2014.

doi: $10.1007 /$ s00253-014-5785-5

[25] Haapalainen AM, Meriläinen G, Wierenga RK. The thiolase superfamily: condensing enzymes with diverse reaction specificities. Trends in biochemical sciences, 31 (1): 64-71, 2006.

doi: 10.1016/j.tibs.2005.11.011

[26] Madhavan A, Sindhu R, Parameswaran B, Sukumaran RK, Pandey A. Metagenome analysis: a powerful tool for enzyme bioprospecting. Applied biochemistry and biotechnology, 183 (2): 636651, 2017.

doi: $10.1007 /$ s12010-017-2568-3

[27] Wilson MC, Piel J. Metagenomic approaches for exploiting uncultivated bacteria as a resource for novel biosynthetic enzymology. Chemistry \& biology. 20 (5): 636-647, 2013.

doi: 10.1016/j.chembiol.2013.04.011

[28] Solomon S, Kachiprath B, Jayanath G, Sajeevan TP, Singh I.B., Philip R. High-quality metagenomic DNA from marine sediment samples for genomic studies through a preprocessing approach. 3 Biotech, 6 (2): 160, 2016.

doi: 10.1007/s13205-016-0482-y

[29] Alma'abadi AD, Gojobori T, Mineta K. Marine metagenome as a resource for novel enzymes. Genomics, proteomics \& bioinformatics, 13 (5): 290-295, 2015.

doi: 10.1016/j.gpb.2015.10.001

[30] Kodzius R, Gojobori T. Marine metagenomics as a source for bioprospecting. Marine genomics, 24: 21-30, 2015.

doi: 10.1016/j.margen.2015.07.001

[31] Lee MH, Lee CH, Oh TK, Song JK, Yoon JH. Isolation and characterization of a novel lipase from a metagenomic library of tidal flat sediments: evidence for a new family of bacterial lipases. Applied and environmental microbiology, 72 (11): 7406-7409, 2006.

doi: 10.1128/AEM.01157-06 
[32] Chu X, He H, Guo C, Sun B. Identification of two novel esterases from a marine metagenomic library derived from South China Sea. Applied microbiology and biotechnology, 80 (4): 615-625, 2008.

doi: 10.1007/s00253-008-1566-3

[33] Jeon JH, Kim JT, Lee HS, Kim SJ, Kang SG, Choi SH, Lee JH. Novel lipolytic enzymes identified from metagenomic library of deep-sea sediment. Evidence-Based Complementary and Alternative Medicine, 2011: 2011.

doi: 10.1155/2011/271419

[34] Okamura Y, Kimura T, Yokouchi H, Meneses-Osorio M, Katoh M, Matsunaga T, Takeyama $H$. Isolation and characterization of a GDSL esterase from the metagenome of a marine spongeassociated bacteria. Marine biotechnology, 12 (4): 395-402, 2010.

doi: 10.1007/s10126-009-9226-x

[35] Su J, Zhang F, Sun W, Karuppiah V, Zhang G, Li Z, Jiang Q. A new alkaline lipase obtained from the metagenome of marine sponge Ircinia sp. World Journal of Microbiology and Biotechnology, 31 (7): 1093-1102, 2015.

doi: 10.1007/s11274-015-1859-5

[36] Martin M. Function-based Analyses of Bacterial Symbionts Associated with the Brown Alga Ascopbyllum nodosum and Identification of Novel Bacterial Hydrolytic Enzyme Genes, Doctoral dissertation, Université de Liège, Liège, Belgique. 2016.

https://orbi.uliege.be/bitstream/2268/196617/1/Th\%C3\%A8se\%20 Marjolaine\%20Martin.pdf

[37] Martin M, Vandermies M, Joyeux C, Martin R, Barbeyron T, Michel G, Vandenbol M. Discovering novel enzymes by functional screening of plurigenomic libraries from alga-associated Flavobacteriia and Gammaproteobacteria. Microbiological Research, 186: 52-61, 2016.

doi: 10.1016/j.micres.2016.03.005

[38] Yung PY, Burke C, Lewis M, Kjelleberg S, Thomas T. Novel antibacterial proteins from the microbial communities associated with the sponge Cymbastela concentrica and the green alga Ulva australis. Applied and environmental microbiology, 77 (4): 1512-1515, 2011.

doi: 10.1128/AEM.02038-10 
[39] Burke C, Kjelleberg S, Thomas T. Selective extraction of bacterial DNA from the surfaces of macroalgae. Applied and environmental microbiology, 75 (1): 252-256, 2009.

doi: 10.1128/AEM.01630-08

[40] Fujimoto S, Nakagami Y, Kojima F. Optimal bacterial DNA isolation method using bead-beating technique. Memoirs Kyushu Univ Dep Of Health Scis Of Medical Sch, 3: 33-38, 2004.

https://www.digital-biology.co.jp/manufactured/products/ms-100/pdf/ report_ms-100_07.pdf

[41] Vandeventer PE, Weigel KM, Salazar J, Erwin B, Irvine B, Doebler R, Niemz A. Mechanical Disruption of Lysis-Resistant Bacterial Cells by Use of a Miniature, Low-Power, Disposable Device. Journal of Clinical Microbiology, 49 (7): 2533-2539, 2011.

doi: 10.1128/JCM.02171-10

[42] Burke C. A metagenomic analysis of the epiphytic bacterial community from the green macroalga Ulva australis. Doctoral dissertation, University of New South Wales, Australia. 2010.

http:// citeseerx.ist.psu.edu/viewdoc/

download?doi $=10 \cdot 1 \cdot 1 \cdot 476 \cdot 3020 \& \mathrm{rep}=$ rep1\&type $=$ pdf

[43] Messaoudi A, Belguith H, Ghram I, Ben Hamida J. LIPABASE: a database for 'true' lipase family enzymes. International journal of bioinformatics research and applications, 7 (4): 390-401, 2011.

doi: 10.1504/IJBRA.2011.043770

[44] Rose TM, Schultz ER, Henikoff JG, Pietrokovski S, McCallum CM, Henikoff S. Consensus-degenerate hybrid oligonucleotide primers for amplification of distantly related sequences. Nucleic acids research, 26 (7): 1628-1635, 1998.

doi: 10.1093/nar/26.7.1628

[45] Rose TM, Henikoff JG, Henikoff S. CODEHOP (COnsensusDEgenerate hybrid oligonucleotide primer) PCR primer design. Nucleic acids research, 31 (13): 3763-3766, 2003.

doi: 10.1093/nar/gkg524

[46] Jaric M, Segal J, Silva-Herzog E, Schneper L, Mathee K, Narasimhan $\mathrm{G}$. Better primer design for metagenomics applications by increasing taxonomic distinguishability. BMC proceedings, 7 (1): 1, 2013.

doi: 10.1186/1753-6561-7-S7-S4 
[47] Dieffenbach CW, Lowe TM, Dveksler GS. General concepts for PCR primer design. PCR Methods Appl, 3 (3): S30-S37, 1993. doi: $10.1093 /$ nar/gkn290

[48] Buck GA, Fox JW, Gunthorpe M, Hager KM, Naeve CW, Pon RT, Rush J. Design strategies and performance of custom DNA sequencing primers. BioTechniques, 27 (3): 528-537, 2018.

doi: $10.2144 / 99273 r r 01$

[49] Kouker G, Jaeger KE. Specific and sensitive plate assay for bacterial lipases. Applied and environmental microbiology, 53 (1): 211 213, 1987.

doi: 0099-2240/87/010211-03

[50] Samad MYA, Razak CNA, Salleh AB, Yunus WZW, Ampon K, Basri M. A plate assay for primary screening of lipase activity, Journal of microbiological methods, 9 (1): 51-56, 1989.

doi: 10.1016/0167-7012(89)90030-4

[51] Lanka S, Latha JNL. A Short Review on Various Screening Methods to Isolate Potential Lipase Producers: Lipases-the Present and Future Enzymes of Biotech Industry. International Journal of Biological Chemistry, 9 (5): 207-219, 2015.

doi: 10.3923/ijbc.2015.207.219

[52] Kumar D, Kumar L, Nagar S, Raina C, Parshad R, Gupta VK. Screening, isolation and production of lipase/esterase producing Bacillus sp. strain DVL2 and its potential evaluation in esterification and resolution reactions. Archives of Applied Science Research, 4 (4): 1763-1770, 2012.

https://www.scholarsresearchlibrary.com/

[53] Tigerstrom RGV, Stelmaschuk S. The use of Tween 20 in a sensitive turbidimetric assay of lipolytic enzymes. Canadian journal of microbiology, 35 (4): 511-514, 1989.

doi: 10.1139 / m89-079

[54] Plou FJ, Ferrer M, Nuero OM, Calvo MV, Alcalde M, Reyes F, Ballesteros A. Analysis of Tween 80 as an esterase/lipase substrate for lipolytic activity assay. Biotechnology techniques, 12 (3): 183-186, 1998.

doi: 10.1023/A:1008809105270 
[55] Corbellini VA, Scroferneker ML, Carissimi M, Stopiglia CDO, Souza TFD. Comparison of lipolytic activity of Sporothrix schenckii strains utilizing olive oil-rhodamine B and tween 80 . Tecno-Lógica, 11 (2): 33-36, 2007.

http://hdl.handle.net/10183/187479

[56] Dittami SM, Duboscq-Bidot L, Perennou M, Gobet A, Corre $\mathrm{E}$, Boyen $\mathrm{C}$, Tonon T. Host-microbe interactions as a driver of acclimation to salinity gradients in brown algal cultures. The ISME journal, 10 (1): 51-63, 2016.

doi: 10.1038/ismej.2015.104

[57] Comba-González NB, Ruiz-Toquica JS, Lopez-Kleine L, Montoya-Castano D. Epiphytic Bacteria of Macroalgae of the Genus Ulva and their Potential in Producing Enzymes Having Biotechnological Interest. Journal of Marine Biology \& Oceanography, 5 (2): 2-9, 2016.

doi: 10.4172/2324-8661.1000153

[58] Devi SG, Fathima AA, Radha S, Arunraj R, Curtis WR, Ramya M. A rapid and economical method for efficient DNA extraction from diverse soils suitable for metagenomic applications. PLoS One, 10 (7): e0132441, 2015.

doi: 10.1371/journal.pone.0132441

[59] Tujula NA, Crocetti GR, Burke C, Thomas T, Holmström C, Kjelleberg S. Variability and abundance of the epiphytic bacterial community associated with a green marine Ulvacean alga. The ISME journal, 4 (2): 301-311, 2009.

doi: $10.1038 /$ ismej.2009.107

[60] Longford SR, Tujula NA, Crocetti GR, Holmes AJ, Holmström C, Kjelleberg S, Taylor MW. Comparisons of diversity of bacterial communities associated with three sessile marine eukaryotes. Aquatic microbial ecology, 48 (3): 217-229, 2007.

doi: 10.3354/ame048217

[61] Bag S, Saha B, Mehta O, Anbumani D, Kumar N, Dayal M, Hansen T. An Improved Method for High Quality Metagenomics DNA Extraction from Human and Environmental Samples. Scientific Reports, 6: 26775, 2016.

doi: $10.1038 / \operatorname{srep} 26775$ 
[62] Ismail A, Ktari L, Ahmed M, Bolhuis H, Bouhaouala-Zahar B, Stal LJ, El Bour M. Heterotrophic bacteria associated with the green alga Ulva rigida: identification and antimicrobial potential. Journal of Applied Phycology, 30 (5): 2883-2899, 2018.

doi: 10.1007/s10811-018-1454-x

[63] Burke C, Thomas T, Lewis M, Steinberg P, Kjelleberg S. Composition, uniqueness and variability of the epiphytic bacterial community of the green alga Ulva australis. ISME Journal: Multidisciplinary Journal of Microbial Ecology, 5 (4): 590$600,2011$.

doi: $10.1038 /$ ismej.2010.164

[64] Dineen SM, Aranda IVR, Anders DL, Robertson JM. An evaluation of commercial DNA extraction kits for the isolation of bacterial spore DNA from soil. Journal of applied microbiology, 109 (6): 1886-1896, 2010.

doi: 10.1111/j.1365-2672.2010.04816.x

[65] Shepherd ML, Swecker JrWS, Ponder MA. Effect of Two Different Commercial DNA Extraction Kits on the Bacterial 16S Ribosomal RNA Gene Denaturing Gradient Gel Electrophoresis Profile of Arabian Gelding Feces. Journal of Equine Veterinary Science, 35 (2): 165-169, 2015.

doi: 10.1016/j.jevs.2014.12.006

[66] Yeates C, Gillings MR, Davison AD, Altavilla N, Veal DA. Methods for microbial DNA extraction from soil for PCR amplification. Biological procedures online, 1 (1): 40-47, 1998.

doi: 10.1251/bpo6

[67] Jensen MA, Fukushima M, Davis RW. DMSO and betaine greatly improve amplification of $\mathrm{GC}$-rich constructs in de novo synthesis. PLoS One, 5 (6): e11024, 2010.

doi: 10.1371/journal.pone.0011024

[68] Farell EM, Alexandre G. Bovine serum albumin further enhances the effects of organic solvents on increased yield of polymerase chain reaction of GC-rich templates. BMC Research Notes, 5 (1): 257-257, 2012.

doi: 10.1186/1756-0500-5-257 
[69] Hardjasa A, Ling M, Ma K, Yu H. Investigating the effects of DMSO on PCR fidelity using a restriction digest-based method. Journal of Experimental Microbiology and Immunology (JEMI), 14: 161-164, 2010.

https://www.microbiology.ubc.ca/sites/default/files/roles/drupal_ungrad/ JEMI/14/JEMI14_161-164.pdf

[70] Bonk BM, Tarasova Y, Hicks MA, Tidor B, Prather KL. Rational design of thiolase substrate specificity for metabolic engineering applications. Biotechnology and bioengineering, 115 (9): 2167-2182, 2018.

doi: $10.1002 /$ bit.26737

[71] Ratledge C. Biochemistry of microbial degradation. Springer Science and Business Media, 2012.

doi: 10.1007/978-94-011-1687-9

[72] Jimenez-Diaz L, Caballero A, Segura A. Pathways for the degradation of fatty acids in bacteria, Aerobic Utilization of Hydrocarbons, Oils and Lipids, Springer, 1-23, 2017.

doi: 10.1007/978-3-319-39782-5_42-1

[73] Fox AR, Soto G, Mozzicafreddo M, Garcia AN, Cuccioloni M, Angeletti M, Ayub ND. Understanding the function of bacterial and eukaryotic thiolases II by integrating evolutionary and functional approaches. Gene, 533 (1): 5-10, 2014.

doi: 10.1016/j.gene.2013.09.096

[74] Harijan RK. Coenzyme-A dependent catalysis: An overview of thiolase superfamily enzymes and drug discovery. Research on Chronic Diseases, 1 (2): 017-019, 2017.

https://www.openaccessjournals.com/articles

[75] Soto G, Stritzler M, Lisi C, Alleva K, Pagano ME, Ardila F, Ayub ND. Acetoacetyl-CoA thiolase regulates the mevalonate pathway during abiotic stress adaptation. Journal of experimental botany, 62 (15): 5699-5711, 2011.

doi: $10.1093 / j x b / e r r 287$

[76] Nesbitt M, Yang X, Fontán P, Kolesnikova I, Smith I, Sampson S, Dubnau E. A thiolase of Mycobacterium tuberculosis is required for virulence and production of androstenedione and androstadienedione from cholesterol. Infection and immunity, 78 (1): 275-282, 2010.

doi: 10.1128/IAI.00893-09 
[77] Martines ACM, Van Eunen K, Reijngoud DJ, Bakker BM. The promiscuous enzyme medium-chain 3-keto-acyl-CoA thiolase triggers a vicious cycle in fatty-acid beta-oxidation. PLoS computational biology, 13 (4): e1005461, 2017.

doi: 10.1371/journal.pcbi.1005461

[78] Wiesenborn DP, Rudolph FB, Papoutsakis ET. Thiolase from Clostridium acetobutylicum ATCC 824 and its role in the synthesis of acids and solvents. Applied and environmental microbiology, 54 (11): 2717-2722, 1988.

https://aem.asm.org/content/54/11/2717

[79] Mann MS, Lütke-Eversloh T. Thiolase engineering for enhanced butanol production in Clostridium acetobutylicum. Biotechnology and bioengineering, 110 (3): 887-897, 2013.

doi: 10.1002/bit.24758

[80] Chung A, Liu Q, Ouyang SP, Wu Q, Chen GQ. Microbial production of 3-hydroxydodecanoic acid by pha operon and fadBA knockout mutant of Pseudomonas putida KT2442 harboring tesB gene. Applied microbiology and biotechnology, 83 (3): 513-519, 2009.

doi: 10.1007/s00253-009-1919-6

[81] Kim EJ, Son HF, Kim S, Ahn JW, Kim KJ. Crystal structure and biochemical characterization of beta-keto thiolase B from polyhydroxyalkanoate-producing bacterium Ralstonia eutropha H16. Biochemical and biophysical research communications, 444 (3): 365-369, 2014.

doi: 10.1016/j.bbrc.2014.01.055

[82] Gao J, Vo MT, Ramsay JA, Ramsay BA. Overproduction of MCL-PHA with high 3-hydroxydecanoate Content. Biotechnology and bioengineering, 115 (2): 390-400, 2018.

doi: 10.1002/bit.26474

[83] Inui H, Ishikawa T, Tamoi M. Wax ester fermentation and its application for biofuel production, Euglena: Biochemistry, Cell and Molecular Biology, Springer, 269-283, 2017.

doi: 10.1007/978-3-319-54910-1_13

[84] Nandavaram A, Sagar AL, Madikonda AK, Siddavattam D. Proteomics of Sphingobium indicum B90A for a deeper understanding of hexachlorocyclohexane $(\mathrm{HCH})$ bioremediation, Reviews on environmental bealth, 31 (1): 57-61, 2016.

doi: 10.1515/reveh-2015-0042 
[85] Bazinet AL, Cummings MP. A comparative evaluation of sequence classification programs. BMC bioinformatics, 13 (1): 92, 2012.

doi: 10.1186/1471-2105-13-92

[86] Patel U, Chandpura J, Chauhan K, Gupte S. Screening and isolation of an organic solvent tolerant lipase producing bacteria from various oil contaminated sites. Indian J. Appl. Microbiol, 21: 22-36, 2018.

http://www.ijamicro.com/21-1-2018/Unisha\%20patel.pdf

[87] Lee LP, Karbul HM, Citartan M, Gopinath SC, Lakshmipriya T, Tang TH. Lipase-secreting Bacillus species in an oil-contaminated habitat: promising strains to alleviate oil pollution. BioMed research international, 2015.

doi: $10.1155 / 2015 / 820575$

[88] Classen T, Kovacic F, Lauinger B, Pietruszka J, Jaeger KE. Screening for Enantioselective Lipases, Hydrocarbon and Lipid Microbiology Protocols, Springer 37-69, 2016.

doi: 10.1007/8623_2016_218

[89] Zottig X, Meddeb-Mouelhi F, Beauregard M. Development of a high-throughput liquid state assay for lipase activity using natural substrates and rhodamine B. Analytical biochemistry, 496: 25-29, 2016.

doi: 10.1016 / j.ab.2015.11.020

[90] Kumar D, Kumar L, Nagar S, Raina C, Parshad R, Gupta VK. Isolation, production and application of lipase/esterase from Bacillus sp. strain DVL43. Journal of Microbiology and Biotechnology Research, 2: 521-528, 2017.

https://pdfs.semanticscholar.org/f959/

bb3f9d549c47f24860f9d61eb4f5110082cc.pdf\%20

[91] Akoh CC, Lee GC, Liaw YC, Huang TH, Shaw JF. GDSL family of serine esterases/lipases. Progress in lipid research, 43 (6): 534-552, 2004.

doi: 10.1016/j.plipres.2004.09.002

[92] Ramnath L, Sithole B, Govinden R. Classification of lipolytic enzymes and their biotechnological applications in the pulping industry. Canadian journal of microbiology, 63 (3): 179-192, 2016.

doi: $10.1139 /$ cjm-2016-0447 
[93] Seghal-Kiran G, Nishanth-Lipton A, Kennedy J, Dobson AD, Selvin J. A halotolerant thermostable lipase from the marine bacterium Oceanobacillus sp. PUMB02 with an ability to disrupt bacterial biofilms. Bioengineered, 5 (5): 305-318, 2014.

doi: 10.4161/bioe. 29898

[94] Kiran GS, Shanmughapriya S, Jayalakshmi J, Selvin J, Gandhimathi R, Sivaramakrishnan S, Natarajaseenivasan K. Optimization of extracellular psychrophilic alkaline lipase produced by marine Pseudomonas sp. (MSI057). Bioprocess and Biosystems Engineering, 31 (5): 483-492, 2008.

doi: 10.1007/s00449-007-0186-0

[95] Selvin J, Kennedy J, Lejon DP, Kiran GS, Dobson AD. Isolation identification and biochemical characterization of a novel halotolerant lipase from the metagenome of the marine sponge Haliclona simulans. Microbial cell factories, 11 (1): 72, 2012.

doi: 10.1186/1475-2859-11-72

[96] Joseph D, Chakraborty K. Production and Biotechnological Application of Extracellular Alkalophilic Lipase from Marine Macroalga-Associated Shewanella algae to Produce Enriched C 20-22 n-3 Polyunsaturated Fatty Acid Concentrate. Applied biochemistry and biotechnology, 185 (1): 55-71, 2017.

doi: 10.1007/s12010-017-2636-8

[97] López-López O, Cerdan M, Gonzalez-Siso M. New extremophilic lipases and esterases from metagenomics. Current Protein and Peptide Science, 15 (5): 445-455, 2014.

doi: 10.2174/1389203715666140228153801

[98] Yuan D, Lan D, Xin R, Yang B, Wang Y. Screening and characterization of a thermostable lipase from marine Streptomyces sp. strain W007. Biotechnology and applied biochemistry, 63 (1): 41-50, 2016.

doi: 10.1002/bab.1338

[99] De Santi C, Leiros HKS, Di Scala A, de Pascale D, Altermark B, Willassen NP. Biochemical characterization and structural analysis of a new cold-active and salt-tolerant esterase from the marine bacterium Thalassospira sp. Extremophiles, 20 (3): 323-336, 2016.

doi: 10.1007/S00792-016-0824-Z 
[100] Hassan SW, Abd El Latif HH, Ali SM. Production of cold active lipase by free and immobilized marine Bacillus cereus HSS: Application in wastewater treatment. Frontiers in microbiology, 9: 2377, 2018.

[101] Esakkiraj P, Prabakaran G, Maruthiah T, Immanuel G, Palavesam A. Purification and Characterization of Halophilic Alkaline Lipase from Halobacillus sp. Proceedings of the National Academy of Sciences, India Section B: Biological Sciences, 86 (2): 309314, 2016.

doi: 10.1007/s40011-014-0437-1

[102] Park SH, Kim SJ, Park S, Kim HK. Characterization of Organic Solvent-Tolerant Lipolytic Enzyme from Marinobacter lipolyticus Isolated from the Antarctic Ocean. Applied biochemistry and biotechnology, 187 (3): 1046-1060, 2019.

doi: 10.1007/s12010-018-2865-5

[103] Deng D, Zhang Y, Sun A, Liang J, Hu Y. Functional characterization of a novel marine microbial GDSL lipase and its utilization in the resolution of $( \pm)-1$-phenylethanol. Applied biochemistry and biotechnology, 179 (1): 75-93, 2016.

doi: 10.1007/s12010-016-1980-4

[104] Urbanek AK, Rymowicz W, Mirończuk AM. Degradation of plastics and plastic-degrading bacteria in cold marine habitats. Applied microbiology and biotechnology, 102 (18): 7669-7678, 2018.

doi: 10.1007/s00253-018-9195-y

[105] Hama S, Noda H, Kondo A. How lipase technology contributes to evolution of biodiesel production using multiple feedstocks. Current opinion in biotechnology, 50: 57-64, 2018.

doi: 10.1016/j.copbio.2017.11.001

[106] Aykin E, Omuzbuken B, Kacar A. Antibiofilm potential of enzymes as ecofriendly antifouling additives. Fresenius environmental bulletin, 27 (6): 4093-4103, 2018.

https://www.researchgate.net/publication/330441108 


\section{Dos posibles enzimas candidatas de bacterias epifíticas asociadas a Ulva lactuca, obtenidas a través de PCR y evaluación funcional}

Resumen: Las bacterias epifíticas de macroalgas marinas sintetizan enzimas de interés industrial y biotecnológico. En este estudio, se obtuvieron dos fragmentos de DNA candidatos para enzimas degradadoras de lípidos del total de DNA de bacterias epifíticas asociadas a Ulva lactuca. En primer lugar, se evaluó un método para el aislamiento del DNA bacteriano total de la superficie del talo de U. lactuca. Posteriormente, se diseñaron conjuntos de primers y se usaron directamente para amplificación por PCR. Los productos PCR resultantes se analizaron por secuenciación y se utilizaron para expresión y evaluación funcional con el sistema Escherichia coli pBAD-TOPO. Se obtuvo DNA bacterial total de alto peso molecular y buena calidad, que sirvió como plantilla para identificar un fragmento correspondiente a una Acetil-CoA C-Acetiltransferasa (o Tiolasa) y un fragmento candidato para una "verdadera" lipasa versátil. El fragmento de gen de la posible "verdadera" lipasa se expresó heterólogamente en Escherichia coli y se obtuvo prueba de actividad hidrolítica en medios de Tributirina, Tween-20 y aceite de oliva. De este estudio resultó nuevo conocimiento sobre bacterias epifíticas asociadas a U. lactuca como posibles nuevas fuentes de enzimas, tales como tiolasas y "verdaderas" lipasas. Sin embargo, se requieren estudios en el futuro que describan las características y aplicaciones importantes de estas enzimas candidatas.

Palabras clave: Bacterias epifíticas; lipasas; PCR; tiolasas; Ulva lactuca. 


\section{Duas possíveis enzimas candidatas de bactérias epifíticas associadas a Ulva lactuca, obtidas através de PCR e avaliação funcional}

Resumo: As bactérias epifíticas de macroalgas marinhas sintetizam enzimas de interesse industrial e biotecnológico. Neste estudo, se obtiveram dois fragmentos candidatos de DNA para enzimas degradantes de lípidos a partir de um DNA total de bactéria epifítica associada a Ulva lactuca. Primeiramente, foi avaliado um método para o isolamento de DNA bacteriano total da superfície do talo de U. lactuca. Posteriormente, se desenharam conjuntos de primers e se usaram diretamente para amplificação por PCR. Os produtos de PCR resultantes foram analisados por sequenciação e se utilizaram para expressão e avaliação funcional com o sistema Escherichia coli pBAD-TOPO. Obtive-se DNA bacteriano total de alto peso molecular e boa qualidade, que serviu como modelo para identificar um fragmento correspondente a uma AcetilCoA C-Acetiltransferase (ou Tiolase) e um fragmento candidato para uma "verdadeira" lipase versátil. O fragmento do gen da possível "verdadeira" lipase se expressou heterologamente em Escherichia coli e se obteve prova de atividade hidrolítica em meios de Tributirina, Tween-20 e aceite de oliva. Este estudo propiciou novos conhecimentos sobre bactérias epifíticas associadas a $U$. lactuca como possíveis novas fontes de enzimas, tais como tiolases e "verdadeiras" lipases. Entretanto, novos estudos são requeridos no futuro que descrevam as características e aplicações importantes de estas enzimas candidatas.

Palavras-chave: Bactérias epifíticas; lipases; PCR; tiolases; Uva lactuca. 


\section{Jordan Steven Ruiz-Toquica}

Marine Biologist from the 'Universidad de Bogotá Jorge Tadeo Lozano' (2013), and MSc. in Microbiology from the 'Universidad Nacional de Colombia' (2017). Currently works as Professor from the 'Departamento de Ciencias Biológicas y Ambientales' at the 'Universidad de Bogotá Jorge Tadeo Lozano'. His interests are focused on the study of microorganisms in marine environments and their biotechnological potential.

ORCID: 0000-0002-5456-2434

\section{Natalia Beatriz Comba-Gonzalez}

Marine Biologist from the Universidad Jorge Tadeo Lozano (2009), MSc. in Microbiology (2011) and PhD in Sciences Biology from the Universidad Nacional de Colombia (2018). Her investigations are focused mainly on the study of epiphytic bacteria associated with marine macroalgae inhabit the Colombian Caribbean to the search of enzymes with biotechnological applications.

ORCID: 0000-0001-6359-8474

\section{Dolly Montoya-Castaño}

Pharmaceutical Chemist from the Universidad Nacional de Colombia (1976), MSc. in Biotechnology from the Universidad Nacional Autónoma de México (1983) and PhD in Natural Sciences from the Technische Universitat Munchen (2003). Her investigations are focused on the study of native microorganism producers of solvents and enzymes with biotechnological and industrial interest.

ORCID: 0000-0001-7891-5452 